Flávia P. Tirelli*, Thales R.O. de Freitas, Fernanda Michalski, Alexandre R. Percequillo and Eduardo Eizirik*

\title{
Using reliable predator identification to investigate feeding habits of Neotropical carnivores (Mammalia, Carnivora) in a deforestation frontier of the Brazilian Amazon
}

https://doi.org/10.1515/mammalia-2018-0106

Received June 15, 2018; accepted October 19, 2018; previously published online December 11, 2018

Abstract: Accurate identification of predator species is a critical requirement to investigate their diet using faecal samples. We used non-invasive sampling and two methods of predator identification to investigate the diets of sympatric carnivores in a highly deforested region of the Brazilian Amazon. Of 108 scats, 81 could be identified at the species level using DNA sequencing and/or trichology. The former performed better than the latter $(81.5 \%$ vs. $54.3 \%$ of the identified samples), and results were quite congruent $(89.7 \%$ concordance in the 29 samples that could be assessed with both approaches). Nine species were identified, out of which four (crab-eating fox, ocelot, puma and jaguar) presented a sufficient number of samples to allow dietary analyses. The crab-eating fox was the most generalist $(B A=0.92)$; ocelots focused on small- to

\footnotetext{
*Corresponding authors: Flávia P. Tirelli, Programa de Pósgraduação em Biologia Animal, Instituto de Biociências, Universidade Federal do Rio Grande do Sul, UFRGS, Av. Bento Gonçalves 9500, Prédio 43435, Bairro Agronomia, Porto Alegre, RS 91501-970, Brazil; and PUCRS, Escola de Ciências, Laboratório de Biologia Genômica e Molecular, 6681 Ipiranga Av., Porto Alegre, RS 90619-900, Brazil, e-mail: flavia.tirelli@gmail.com; and Eduardo Eizirik, PUCRS, Escola de Ciências, Laboratório de Biologia Genômica e Molecular, 6681 Ipiranga Av., Porto Alegre, RS 90619900, Brazil; and Instituto Pró-Carnívoros, C.P. 10, Atibaia, SP 12940970, Brazil, e-mail: eduardo.eizirik@pucrs.br Thales R.O. de Freitas: Programa de Pós-graduação em Biologia Animal, Instituto de Biociências, Universidade Federal do Rio Grande do Sul, UFRGS, Av. Bento Gonçalves 9500, Prédio 43435, Bairro Agronomia, Porto Alegre, RS 91501-970, Brazil; and Departamento de Genética, Instituto de Biociências, Universidade Federal do Rio Grande do Sul, Campus do Vale, Av. Bento Gonçalves 9500, prédio 43323, Porto Alegre, RS 9150197, Brazil Fernanda Michalski: Laboratório de Ecologia e Conservação de Vertebrados, Universidade Federal do Amapá, Rodovia Juscelino Kubitschek, km 02, Bloco T, Macapá, AP 68903-419, Brazil; and Instituto Pró-Carnívoros, C.P. 10, Atibaia, SP 12940-970, Brazil Alexandre R. Percequillo: Departamento de Ciências Biológicas, Escola Superior de Agricultura "Luiz de Queiroz", Universidade de São Paulo, Av. Pádua Dias 11, Caixa Postal 9, Piracicaba, São Paulo 13418-900, Brazil; and Department of Life Sciences, The Natural History Museum, Cromwell Road, London SW7 5BD, UK
}

medium-sized prey; pumas fed mostly on medium-sized items; and jaguars mostly targeted large-sized prey. A considerable overlap was observed between ocelots and pumas in all estimations $(O=0.47-0.83)$. The presence of jaguars in the same region could be driving pumas to select medium- and small-sized prey. The results of this study highlight the importance of reliable predator identification and the need for in-depth ecological studies in areas where carnivore species are sympatric.

Keywords: carnivorans; diet; DNA barcoding; trichology.

\section{Introduction}

Carnivores are considered to be very important ecosystem components (Miller and Rabinowitz 2002), with their absence resulting in biodiversity loss and other ecological changes (Terborgh et al. 2001). Competition for food resources associated with dietary flexibility has been inferred to play a relevant role in various carnivore guilds. Therefore, dietary studies of sympatric carnivores are crucial to understand these processes, as they allow comparative assessments of their feeding strategies and competitive interactions.

Dietary studies of wild carnivores often rely on the identification of prey items in faecal samples. In an area harbouring several sympatric carnivores, it is therefore critical to reliably identify the species of origin of each sample (Farrell et al.2000). Traditional methods to identify predator species from faecal samples include monitoring latrine sites, using tracks found near the scat or features such as odour and morphology (size, shape) (Pedó et al. 2006, De la Torre and De la Riva 2009). However, these techniques have often been found to be inconsistent and unreliable, as there are frequent overlaps in these features among sympatric carnivore species (Farrell et al. 2000). Consequently, other techniques have been developed. One of these methods, trichology, employs microscopy of predator guard hairs (swallowed during self-grooming), and has been used in numerous dietary studies (e.g. Gatti et al. 2006, Quadros and Monteiro-Filho 2006a,b, Silva-Pereira 2009, Rocha-Mendes et al. 2010). Another 
technique is to use DNA sequences (i.e. a DNA barcoding approach), which has been shown to be a powerful tool for identifying carnivore species (Farrell et al. 2000, Chaves et al. 2012). As a consequence, several studies have already used DNA-based approaches to identify carnivores in dietary studies (e.g. Farrell et al. 2000, Napolitano et al. 2008, Martínez-Gutiérrez et al. 2015, Morin et al. 2016). As both trichology and DNA barcoding are now commonly used in these studies, it is interesting to compare their performance with the same set of samples to assess their relative efficiency and reliability.

The Amazon forest hosts $\sim 25 \%$ of global biodiversity, including jaguars Panthera onca (Linnaeus, 1758), pumas Puma concolor (Linnaeus, 1771) and ocelots Leopardus pardalis (Linnaeus, 1758) (Malhi et al. 2008, Macdonald and Loveridge 2010). However, this biome has been suffering impacts such as climate change and deforestation (Malhi et al. 2008, Barlow et al. 2016). Currently, the epicentre of Amazon deforestation is known as the "deforestation arc", located in Eastern and Southern Amazonia. The region of Alta Floresta, included in this arc, is one of the most deforested areas of the Brazilian Amazon, and thus has become highly fragmented, resulting in both habitat loss and isolation of the remaining natural patches. Michalski et al. (2008) reported high deforestation rates in the area since the early 1980s, with the original forest cover declining from $91 \%$ in 1984 to $42 \%$ in 2004 and 35\% in 2016 (Michalski and Peres 2016) on the southern bank of the Teles Pires River, driven by economic activities such as cattle ranching and farming. In this region, Michalski and Peres (2007) recorded 15 carnivoran species, from the top predator, jaguar, to the opportunistic crab-eating fox Cerdocyon thous (Linnaeus, 1766).

Few studies have so far analysed the diet of carnivorans in the Amazon forest (e.g. Rosas et al. 1999, Ramalho 2006, Cabral et al. 2010, these studies used latrine sites, tracks found near the scat, odour and/or size to identify predators) and no published study on carnivoran diet has focused on the southern Brazilian Amazon. Therefore, in the present study, we aimed to compare two methods of predator species identification based on scat samples (hair microscopy vs. DNA barcoding) so as to make broader recommendations on their applicability in this field. In addition, incorporating these results in predator identification, we aimed to describe and compare the diet of sympatric carnivorans in one of this area.

\section{Materials and methods}

\section{Study area}

We carried out this study in Alta Floresta municipality $\left(09^{\circ} 53^{\prime} \mathrm{S}, 56^{\circ} 28^{\prime} \mathrm{W}\right)$, located in northern Mato Grosso state, in the southern Brazilian Amazon. The study area (Figure 1)

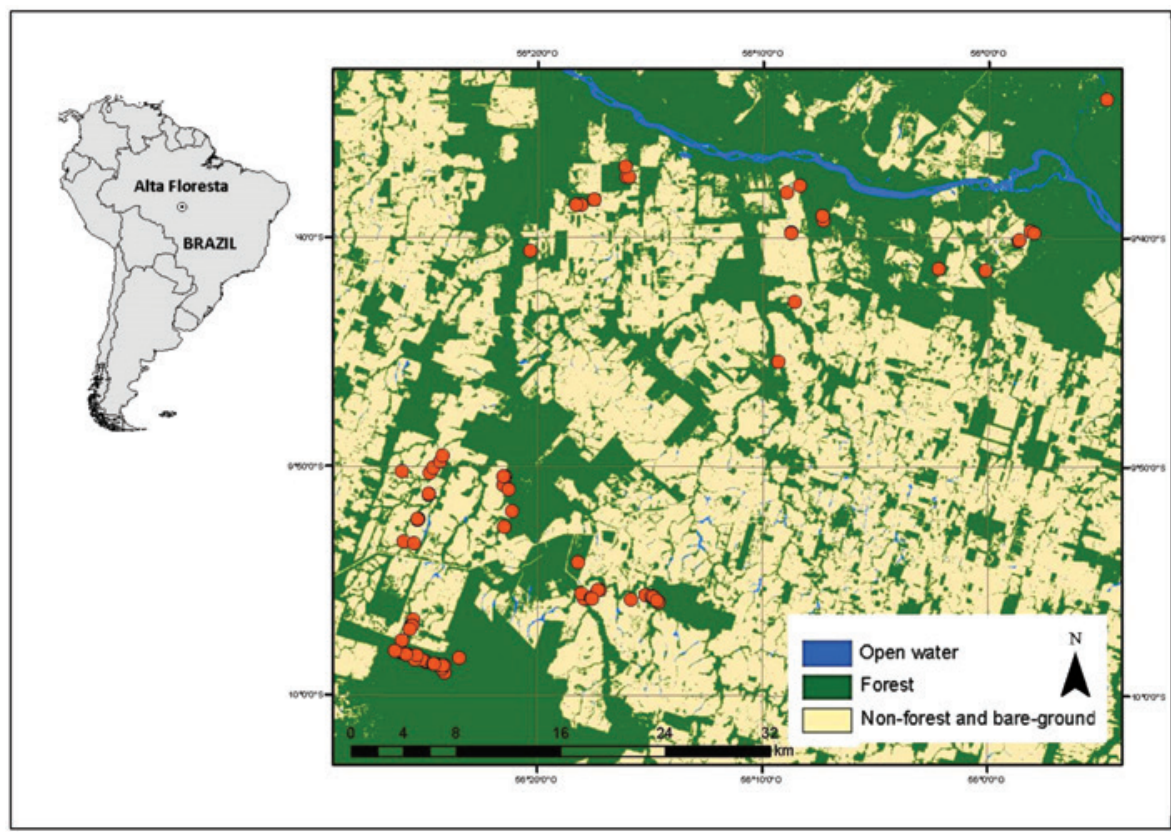

Figure 1: Map of the study area in Alta Floresta, Brazil, and the classified Landsat 5 TM image showing the location of the 108 carnivore scat samples (orange circles) included in the analyses. 
encompassed at least $7295 \mathrm{~km}^{2}$ (Michalski and Peres 2017). The climate was classified by Köppen (1948) as Amazon (tropical monsoon climate), also known as a "tropical wet climate". The average annual precipitation is $2350 \mathrm{~mm}$. The mean annual temperature is $24.5^{\circ} \mathrm{C}$, and there is high relative air humidity (80-85\%) (Radam-Brasil 1983).

\section{Faecal sampling and identification of predator species from scats}

Carnivoran scats were collected opportunistically from October 2007 to December 2008, and identified at the species level using two different approaches: a molecular (DNA barcoding) assay and a trichological approach (microscopy-based analysis of guard hairs). The former is based on the polymerase chain reaction (PCR) amplification and sequencing of short segments of the mitochondrial DNA (mtDNA), followed by comparisons to a reference database (Michalski et al. 2011, Chaves et al. 2012). For this molecular approach, a portion of $\sim 5 \mathrm{~cm}$ in length of each scat was collected, immersed in $96 \%$ ethanol and stored at $-20^{\circ} \mathrm{C}$ prior to DNA extraction. The remaining portion of each scat was stored in a zip-lock bag for use in the hair microscopy-based carnivore identification and in the dietary analysis.

The identification using hair microscopy was performed independently from the DNA-based approach. We searched for predator hairs contained in the scats, and then isolated them from the remaining material; this procedure was possible as prey hairs are much more numerous and form tufts, while predator hairs are usually scarce and dispersed individually. Subsequently, carnivore hairs were prepared on glass slides following the technique developed by Quadros and Monteiro-Filho (2006b). Hair microstructures (hair medulla and cuticular scales) were compared to a collection of slides prepared specifically for this study, using hairs collected from reference specimens of multiple carnivoran species housed in the mammalogy collection of Museu de Ciências Naturais - Fundação Zoobotânica do Rio Grande do Sul (MCN-FZB/RS).

To test the efficacy and reliability of these methods, we: (i) evaluated the number of samples identified by each of them relative to the total number; and (ii) evaluated if both methods identified the same species in cases where both could be applied and compared their results with a "blind test". In addition, we tested the identification method that is based on the perimeter of the scats, using a tape measure on all scat samples that were not deformed. Using the identifications originated by molecular and/or hair microscopy methods, we compared the perimeter of scats between different species, and tested its significance using Student's t-test with a 99\% confidence level.

\section{Dietary data collection}

Faecal samples were washed with flowing water using two sizes of fine-mesh filters (1.0 and $0.5 \mathrm{~mm})$. The organic material was then separated, with remaining muscles of vertebrates and invertebrates being immersed in ethanol $70 \%$, whilst feathers, plants, teeth, claws, bones, etc. were sun-dried in thin paper bags for 3 days to avoid fungal growth (adapted from Carss and Parkinson 1996). For every scat sample, we created a record with information on all the food items it contained, which were initially identified to a broad taxonomic level (i.e. mammal, bird, non-avian reptile, amphibian, etc.).

We identified food items by examining the undigested material, which varied among prey groups. Small mammals were identified through the comparative study of claws, hairs and molars with specimens housed in the Laboratório de Mamíferos - Escola Superior de Agricultura "Luiz de Queiroz", Universidade de São Paulo (LMUSP). Medium-sized and large mammals were identified using a hair reference collection built from specimens housed in the following museums: Museu de Ciências e Tecnologia - Pontifícia Universidade Católica do Rio Grande do Sul (MCT-PUCRS), Museu de Ciências Naturais - Fundação Zoobotânica do Rio Grande do Sul (MCN-FZB) and Museu Nacional - Universidade Federal do Rio de Janeiro (MNUFRJ). Bird feet, beaks and feathers were compared macroscopically to a reference collection from MCT-PUCRS, in addition to slides with feathers used in microscopical identification compared to an identification key (Brom 1986). A reference collection from the Laboratório de Ictiologia of Universidade Federal do Rio Grande do Sul (UFRGS) was used for fish identification. Reptiles and invertebrates were identified by zoologists from UFRGS working on these groups.

\section{Dietary analysis}

Quantitative dietary analyses were performed only for species with sufficient sample size $(n \geq 8)$. The frequency of occurrence $(F O)$ was quantified by the presence of the food item in the total faecal samples. In addition, we measured its proportion of occurrence $(P O)$ by dividing the total number of occurrences of that particular prey by the total number of items (Wang 2002). 
The $F O$ tends to overestimate the relative consumption of small items (Villa-Meza et al. 2002) and underestimates the relative consumption of large prey (Weaver 1993). To overcome this problem, some studies with pumas (Ackerman et al. 1984) and bobcats (Lynx rufus, Baker et al. 1993, 2001) developed a correction algorithm based on feeding trials in captivity using known prey of different body sizes. Studies with Asian and South American fauna have used these equations in mammalian carnivores with body sizes similar to the original species (Villa-Meza et al. 2002, Andheria et al. 2007, Martins et al. 2008). In the present study, the correction algorithm for puma was used for the puma and jaguar samples $(Y=1.98+0.035 X)$, while the bobcat correction was used for ocelots $(Y=16.63+4.09 X)$, where $X$ is the live weight of the prey (Ackerman et al. 1984, VillaMeza et al. 2002, Azevedo 2008, Martins et al. 2008). We only applied the index to the mammalian prey of these three felids, as this was the group for which we were able to perform the most precise identification. It was also the most frequent category of vertebrate prey in the diet of all three cats. Live weight estimates of prey items were based on published references (Ackerman et al. 1984, Emmons 1987, Bonvicino et al. 2008). With respect to smaller prey $(<1 \mathrm{~kg})$, we did not calculate the correction factor because predators usually ingest the entire animal (Ackerman et al. 1984, Campos 2009).

The relative biomass $(R B)$ of each item $i$ in the diet of species $k$ was calculated using the correction factor $(Y)$ and the $F O$ (Ackerman et al. 1984, Villa-Meza et al. 2002, Andheria et al. 2007): $R B_{k i}=\left[\left(F O_{k i} \cdot Y_{k i}\right) / \sum_{i=1}^{n} F O_{k i} \cdot Y_{k i}\right] \cdot 100$. Prey items were divided into three body size categories: small $(<1 \mathrm{~kg})$, medium $(1-15 \mathrm{~kg})$, and large $(>15 \mathrm{~kg})$ (Iriarte et al. 1990). To evaluate the importance of each prey item in the diet of jaguars, pumas and ocelots, the index of relative importance (IRI) from Pinkas et al. (1971) was measured as: $I R I=(P O+R B) F O$.

We used the normalized Levins' measure of standardized niche breadth (Hulbert 1976, see also Krebs 1999) to estimate the food niche breadth of each of these three carnivoran species, as follows:

$$
\hat{B}_{A}=(\hat{B}-1) /(n-1)
$$

where $B$ is Levins' measurement $\left(\hat{B}=1 / \sum_{i=1}^{n} \hat{p}_{i}^{2}\right), \hat{p}_{i}$ is the fraction of items in the diet that belong to food category $i$; and $n$ is the number of possible resource states. The values of niche breadth can range from 0 (small diversity of prey consumed at high frequencies, i.e. the predator is more of a specialist than a generalist) to 1 (resources are used in similar frequencies, i.e. the predator is more of a generalist) (Krebs 1999).
The dietary niche overlap $(O)$ between these three felids was calculated using two indices in order to compare their results: Pianka’s (1973) measure:

$$
O_{12}=O_{21}=\sum_{i=1}^{n}\left(p_{k i} \cdot p_{l i}\right) / \sqrt{\sum_{i=1}^{n} p_{k i} \cdot \sum_{i=1}^{n} p_{l i}}
$$

and Czekanowski's index (1913), also known as Sørensen's index (1948):

$$
O_{12}=O_{21}=1.0-0.5 \cdot\left[\sum_{i=1}^{n}\left(p_{k i}-p_{l i}\right)\right],
$$

where $p_{1 i}$ and $p_{2 i}$ are the proportions of resource $i$ in the diet of the species $k$ and $l$, respectively.

These indices range from 0 (no overlap) to 1 (complete overlap) (Sørensen 1948, Krebs 1999). The niche overlap was measured considering the $P O$ of all vertebrate items, and using the $R B$ of mammalian prey for both indices. The bootstrap of niche overlap between species was calculated using the function niche.overlap. boot, with 999 iterations and a confidence interval between 0.025 and 0.975 . We carried out these analyses using the package "spaa" (Zhang 2016) of the software R 3.2.3. (R Development Core Team 2015). We also tested these same data $(P O$ and $R B$ ) for significance of niche overlap by comparing the observed values with values obtained by randomizing the original matrices (5000 iterations), using the default procedure (RA3) implemented in the package "EcoSimR" 0.1.0 (Gotelli et al. 2015) in R. Additionally, we used the Bray-Curtis similarity coefficient (Bray and Curtis 1957) to examine the similarity in the $P O$ of vertebrate items among the three species. The Bray-Curtis similarity coefficient for species $k$ is defined as:

$$
S=\left[\sum\left(x_{k i}-x_{k j}\right) /\left(\sum\left(x_{k i}+x_{k j}\right)\right)\right]
$$

where $x_{k i}$ is the count of the $i$ th prey species for predator species $k$. We used the package "vegan" (Oksanen et al. 2017) in R to calculate Bray-Curtis similarity and to perform a subsequent cluster analysis.

Arthropod fragments and plant material were not included in the analyses of the three felid species (Villa-Meza et al. 2002). However, these items were included in the Cerdocyon thous analysis, as they may play a more important role in its diet (Jácomo et al. 2004, Gatti et al. 2006, Rocha et al. 2008). Thus, the niche overlap between felids and $C$. thous was not calculated in this study. 


\section{Results}

\section{Methods of predator identification}

A total of 108 faecal samples was collected, and of these, 81 could be identified at the species level. Of these samples, 66 (81.5\%) were identified using the molecular method (as reported by Michalski et al. 2011), while 44 (54.3\%) were identified with trichology. Twenty-nine samples could be identified with both methods (Table 1), allowing a comparison of their performance. We observed a concordance of $89.7 \%$ in species identification, and thus a $10.3 \%(n=3)$ discrepancy in the identifications (Table S1). We chose to preferentially follow the molecular identification, as this approach always included reagent-only controls, decreasing the chance of contamination, while trichology involves a subjective assessment of hair microstructural patterns.

We used the 66 scats that were successfully identified with the molecular approach, along with the 15 samples that were only identified with trichology to investigate the diets of predator species. In this combined sample set, we identified nine different predator species (Table 1). With regard to the trichology approach, of all the samples that contained guard hairs $(n=65)$, we identified 44 to the species level, five at the family level (all Felidae, Table S1)

Table 1: Number of faecal samples from Alta Floresta, Brazil, whose source predator species could be successfully identified with the molecular approach, trichology or both methods.

\begin{tabular}{|c|c|c|c|c|}
\hline Predators & Molecular ${ }^{a}$ & Hair microscopy & Congruence in both methods & Total \\
\hline \multicolumn{5}{|l|}{ Felidae } \\
\hline Panthera onca & 13 & 7 & 4 & 16 \\
\hline Puma concolor & 7 & 2 & 1 & 8 \\
\hline Puma yagouaroundi & 2 & $1(2)^{b}$ & 0 & 3 \\
\hline Leopardus pardalis & 16 & $10(11)^{b}$ & 8 & 18 \\
\hline \multicolumn{5}{|l|}{ Canidae } \\
\hline Cerdocyon thous & 24 & $18(19)^{\mathrm{b}}$ & 13 & 29 \\
\hline \multicolumn{5}{|l|}{ Mustelidae } \\
\hline Lontra longicaudis & 1 & 1 & 0 & 2 \\
\hline Pteronura brasiliensis & 2 & 0 & 0 & 2 \\
\hline Eira barbara & 0 & 2 & 0 & 2 \\
\hline Speothos venaticus & 1 & 0 & 0 & 1 \\
\hline Total & 66 & $41(44)^{b}$ & $26^{c}$ & 81 \\
\hline
\end{tabular}

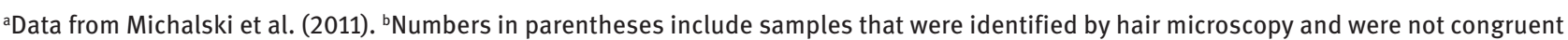
with the molecular identification; as we chose to preferentially follow the molecular identification, these numbers are only an indication of how many samples were identified with hair microscopy, including cases of putatively incorrect identification. ${ }^{~}$ The total number of samples identified by both methods was 29; however, three samples were differently identified by both methods (see Table S1).

Table 2: Size variation in carnivoran scats $(n=81)$ from Alta Floresta, Brazil.

\begin{tabular}{|c|c|c|c|c|c|c|c|}
\hline Predators & $\mathbf{N}$ & DS & $\operatorname{Min}-\max (\mathrm{mm})$ & $\mathrm{Cl}(95 \%)$ & Mean \pm SD & t-test & p-Value \\
\hline \multicolumn{8}{|l|}{ Felidae } \\
\hline Panthera onca & 8 & 8 & $60-140$ & $64.9-116.8$ & $90.9 \pm 28.1$ & 8.6 & $<0.01$ \\
\hline Puma concolor & 1 & 6 & 106 & - & - & - & - \\
\hline Puma yagouaroundi & 0 & 3 & - & - & - & - & - \\
\hline Leopardus pardalis & 10 & 8 & $35-85$ & $47.2-73.9$ & $60.6 \pm 18.7$ & 10 & $<0.01$ \\
\hline \multicolumn{8}{|l|}{ Canidae } \\
\hline Cerdocyon thous & 13 & 17 & $40-110$ & $59.0-83.9$ & $71.5 \pm 20.6$ & 13 & $<0.01$ \\
\hline Speothos venaticus & 0 & 1 & - & - & - & - & - \\
\hline \multicolumn{8}{|l|}{ Mustelidae } \\
\hline Eira barbara & 1 & 1 & 70 & - & - & - & - \\
\hline Lontra longicaudis & 1 & 1 & 63 & - & - & - & - \\
\hline Pteronura brasiliensis & 0 & 2 & - & - & - & - & - \\
\hline
\end{tabular}

The table indicates the circumference of scat samples identified with the molecular and/or trichology approaches. N, number of scats that could be measured; DS, number of deformed scats; Cl, confidence interval; SD, standard deviation. 
and 16 samples remained unidentified due to the high level of hair degradation and/or unclear microstructural patterns.

The circumference of scats was assessed for samples already identified by the other methods (molecular and/or hair microscopy). However, 58.03\% of scats (including all the puma samples) were deformed, precluding adequate measurement. The assessment of the remaining samples (Table 2) revealed overlap in the circumference among almost all species. In addition, for the species with sufficient samples to apply t-tests, we observed that all comparisons were non-significant (jaguar $\times$ ocelot: $t=2.49, d f=9.67, \mathrm{p}=0.03$; jaguar $\times$ crab-eating fox: $t=1.61$, $d f=9.57, \mathrm{p}=0.14$; and ocelot $\times$ crab-eating fox: $t=1.32$, $d f=20.3, \mathrm{p}=0.20$ ).

\section{Dietary analysis}

Prey items were surveyed for all the identified predator species (Tables 3 and 4; Table S2; Table S3), but quantitative dietary analyses were performed only for Panthera onca, Puma concolor, Leopardus pardalis and Cerdocyon thous, which had larger sample sizes. For the other predator species (Puma yagouaroundi, Lontra longicaudis, Pteronura brasiliensis, Eira barbara), we only provide a qualitative description of their diet (Table S3).

Cerdocyon thous - Thirty different items were recognized in the crab-eating fox scats. Twenty-three were animal matter (76.67\%), and seven were plant matter (23.33\%). Among the animal items, we identified mammals $(2.23 \%)$, birds $(1.12 \%)$, reptiles $(8.38 \%)$ and invertebrates $(88.27 \%)$. In the most frequent vertebrate category (reptiles), we found three species of lizards, one identified at the family level (Teiidae), another at the suborder level (Lacertilia) and another at the order level (Squamata); we also identified two species of snakes, one of which was identified at the family level (Colubridae) and the other at the suborder level (Serpentes). The insect order Coleoptera was the most frequent among all animal matter. Seeds were the most consumed item by the crabeating fox $(F O=96.55$ and $P O=60.92)$, which was the carnivoran species that presented the largest variety of items (Table 3). Additionally, we found a human waste item (plastic) in one of the samples.

Panthera onca - Ten vertebrate prey categories were detected in the jaguar diet (Table S3). Mammals appeared in all scat samples and presented the highest frequency in the jaguar diet $(F O=100$ and $P O=84.21)$, with $68.75 \%$ being large species and $31.25 \%$ being medium-sized ones. The most frequent items were Tayassu pecari and Pecari
Table 3: Frequency of occurrence $(F O)$ and proportion of occurrence $(P O)$ of prey consumed by the crab-eating fox (Cerdocyon thous) in Alta Floresta.

\begin{tabular}{|c|c|c|c|c|}
\hline & $\begin{array}{r}F O \\
\mathrm{~N}\end{array}$ & $\begin{array}{r}(\text { Scats }=29) \\
\%\end{array}$ & $\begin{array}{r}P O \\
\mathrm{~N}\end{array}$ & $\begin{array}{r}(\text { Items }=459) \\
\%\end{array}$ \\
\hline \multicolumn{5}{|l|}{ Mammals } \\
\hline Agouti paca & 1 & 3.448 & 1 & 0.218 \\
\hline Unidentified rodent & 3 & 10.344 & 3 & 0.655 \\
\hline \multicolumn{5}{|l|}{ Birds } \\
\hline Turdus sp. & 1 & 3.448 & 1 & 0.218 \\
\hline Anatidade & 1 & 3.448 & 1 & 0.218 \\
\hline \multicolumn{5}{|l|}{ Reptiles } \\
\hline Colubridae & 4 & 13.793 & 4 & 0.873 \\
\hline Teiidae & 2 & 6.896 & 2 & 0.437 \\
\hline Lacertilia & 7 & 24.138 & 7 & 1.528 \\
\hline Serpentes & 1 & 3.448 & 1 & 0.218 \\
\hline Unidentified Squamata & 1 & 3.448 & 1 & 0.218 \\
\hline \multicolumn{5}{|l|}{ Invertebrates } \\
\hline Gastropoda & 1 & 3.448 & 1 & 0.218 \\
\hline \multicolumn{5}{|l|}{ Arthropods } \\
\hline Trichodactylidae & 1 & 3.448 & 1 & 0.218 \\
\hline Crustacea & 1 & 3.448 & 1 & 0.218 \\
\hline Diptera & 2 & 6.896 & 2 & 0.437 \\
\hline Scarabaeidae & 15 & 51.724 & 90 & 19.651 \\
\hline Carabidae & 1 & 3.448 & 1 & 0.218 \\
\hline Coleoptera & 8 & 27.586 & 40 & 8.734 \\
\hline Formicidae & 3 & 10.345 & 3 & 0.655 \\
\hline Apidae & 1 & 3.448 & 1 & 0.218 \\
\hline Lepidoptera & 1 & 3.448 & 1 & 0.218 \\
\hline Hemiptera & 1 & 3.448 & 1 & 0.218 \\
\hline Orthoptera & 8 & 27.586 & 8 & 1.747 \\
\hline Auchenorrhyncha & 1 & 3.448 & 2 & 0.437 \\
\hline Unidentified Arthropoda & 5 & 17.241 & 6 & 1.31 \\
\hline \multicolumn{5}{|l|}{ Plants } \\
\hline Poaceae (seed) & 7 & 24.138 & 18 & 3.93 \\
\hline Arecaceae & 1 & 3.448 & 2 & 0.437 \\
\hline Unidentified palm & 4 & 13.793 & 5 & 1.092 \\
\hline Fruit & 4 & 13.793 & 4 & 0.873 \\
\hline Seed \#1 & 4 & 13.793 & 55 & 12.01 \\
\hline Seed \#2 & 7 & 24.138 & 177 & 38.646 \\
\hline Seed \#3 & 1 & 3.448 & 18 & 3.93 \\
\hline \multicolumn{5}{|l|}{ Human waste } \\
\hline Plastic & 1 & 3.448 & 1 & 0.218 \\
\hline
\end{tabular}

tajacu, the former with the highest $R B$, which was also corroborated by the IRI, which showed it as the most important prey item for this species. It is noteworthy that we found one livestock prey (Bos taurus indicus) in one jaguar sample (Table 4).

Puma concolor - Seven vertebrate categories were found in the puma scats (Table 4; Table S3). Rodents were the most frequent item $(F O=50$ and $P O=57.16)$. The item with the highest $R B$ and IRI was Dasypus sp. (Table 4).

Leopardus pardalis - For the ocelot scats, we identified 19 different vertebrate categories. Proechimys sp. was the 


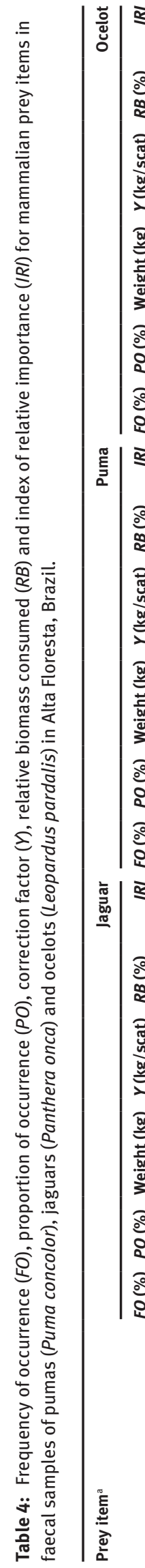

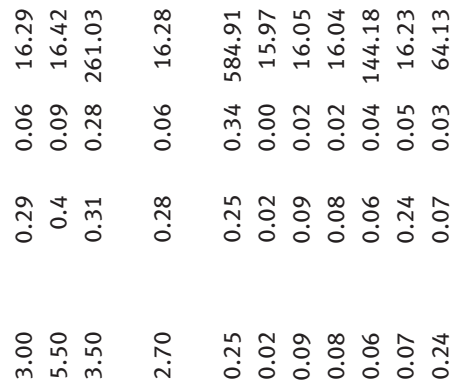

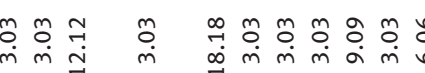

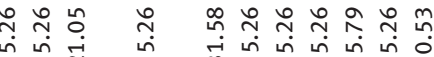

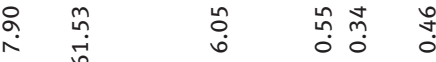

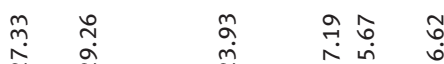

ণิ)

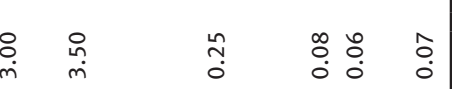

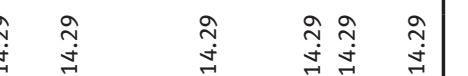

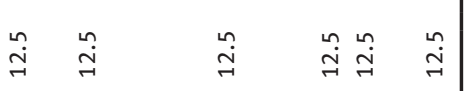

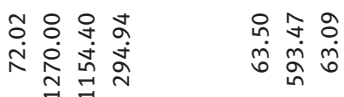

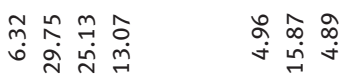

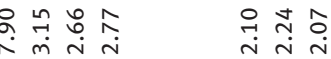

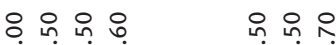

ดิ

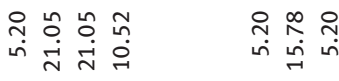

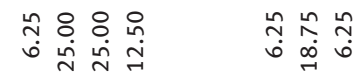

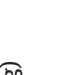

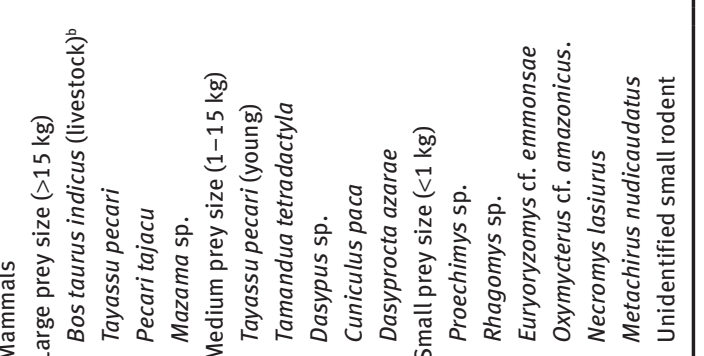


Table 5: Levins' measure of niche breadth $(\hat{B})$ and standardized niche breadth $\left(\hat{B}_{A}\right)$ for four predators from Alta Floresta: crab-eating fox (Cerdocyon thous), jaguars (Panthera onca), puma (Puma concolor) and ocelot (Leopardus pardalis).

\begin{tabular}{lrr}
\hline & $\hat{\boldsymbol{B}}$ & $\hat{\boldsymbol{B}}_{A}$ \\
\hline Crab-eating fox & 21.173 & 0.917 \\
Jaguar & 10.362 & 0.339 \\
Puma & 7 & 0.857 \\
Ocelot & 12.663 & 0.364 \\
\hline
\end{tabular}

most frequent item, followed by Dasypus sp. Proechimys sp. exhibited the highest $R B$, and the IRI showed it as the most important prey item in the ocelot diet (Table 4).

The niche breadth $(B$ and $B A$ ) of jaguar, puma and ocelot was lower than that of the crab-eating fox (Table 5). Among the three felids, the ocelot and puma presented the largest niche overlap (Table 6), using both indices (Pianka and Czekanowski). Using $P O$ and $R B$, the results were not significantly different from random expectations (Figures 2 and 3). Additionally, the Bray-Curtis similarity coefficients between the $P O$ of vertebrate prey in the jaguar, puma and ocelot diet indicated a medium to high similarity between the puma and ocelot diets (Figure 4).

\section{Discussion}

\section{Predator species identification}

The data collected in this study allowed an assessment of two methods of carnivoran faecal identification, and provided insights into the diet of carnivorans in one of the most deforested areas of the Brazilian Amazon. This area presents harsh conditions for fieldwork, posing challenges to finding scats on trails. Furthermore, scat removal by dung beetles is an added problem, as they can remove up to $71 \%$ of faecal samples in $24 \mathrm{~h}$ (Norris and Michalski 2010). Given these issues, it is challenging to obtain large numbers of scats in the area, making it critical to perform careful predator identification of the obtained samples to maximize the reliability of the dietary assessments, in light of limited sample sizes.

The DNA-based method has been successful in dietary studies (e.g. Farrell et al. 2000, Napolitano et al. 2008, Martínez-Gutiérrez et al. 2015, Morin et al. 2016) and so has the trichology approach (e.g. Silva-Pereira 2009, Rocha-Mendes et al. 2010). In this comparative study, the molecular method was more successful than the trichology approach, given the larger number of samples identified by the former vs. the latter. The DNA-based method seemed to be affected by the scat age (e.g. if it was too old or dry); overall, we considered 93 samples as feasible for molecular identification, while the others were excluded due to severe deterioration. Samples obtained in the tropics are often exposed to high humidity, warm temperatures, frequent rain and intense sunlight, all of which can rapidly degrade DNA (Michalski et al. 2011). The hair microscopy approach depended on finding predator guard hairs in the faecal sample $(n=65)$, and also on the level of degradation of these hairs. Both methods faced some obstacles, but mostly presented consistent identification, and complemented each other when considering the total set of identified samples. As for the identification method based on the circumference of scats, the results showed that it presents very low reliability, agreeing with previous

Table 6: Pianka's and Czekanowski's indices [observed $(O)$ and bootstrap (Bot, mean \pm SD)] of niche overlap between jaguar (Panthera onca), puma (Puma concolor) and ocelot (L. pardalis) from Alta Floresta, Brazil, calculated with two categories: proportion of occurrence of vertebrate prey $(P O)$ and relative biomass of mammalian prey $(R B)$.

\begin{tabular}{|c|c|c|c|c|c|c|}
\hline Type of data & Index & Pair of species & 0 & Bot & Bot (Cl1) & Bot $(\mathrm{Cl} 2)$ \\
\hline \multirow[t]{6}{*}{$P O$ (vertebrates) } & \multirow[t]{3}{*}{ Pianka } & Jaguar-puma & 0.052 & $0.055 \pm 0.054$ & 0.00 & 0.18 \\
\hline & & Jaguar-ocelot & 0.089 & $0.100 \pm 0.077$ & 0.00 & 0.28 \\
\hline & & Puma-ocelot & 0.689 & $0.677 \pm 0.119$ & 0.43 & 0.85 \\
\hline & \multirow[t]{3}{*}{ Czekanowski } & Jaguar-puma & 0.052 & $0.054 \pm 0.058$ & 0.00 & 0.20 \\
\hline & & Jaguar-ocelot & 0.113 & $0.118 \pm 0.064$ & 0.00 & 0.26 \\
\hline & & Puma-ocelot & 0.476 & $0.463 \pm 0.114$ & 0.21 & 0.65 \\
\hline \multirow[t]{6}{*}{$R B$ (mammals) } & \multirow[t]{3}{*}{ Pianka } & Jaguar-puma & 0.067 & $0.073 \pm 0.082$ & 0.00 & 0.27 \\
\hline & & Jaguar-ocelot & 0.081 & $0.094 \pm 0.082$ & 0.00 & 0.31 \\
\hline & & Puma-ocelot & 0.833 & $0.810 \pm 0.141$ & 0.4 & 0.97 \\
\hline & \multirow[t]{3}{*}{ Czekanowski } & Jaguar-puma & 0.050 & $0.06 \pm 0.072$ & 0.00 & 0.26 \\
\hline & & Jaguar-ocelot & 0.099 & $0.104 \pm 0.084$ & 0.00 & 0.31 \\
\hline & & Puma-ocelot & 0.674 & $0.647 \pm 0.141$ & 0.29 & 0.85 \\
\hline
\end{tabular}


Proportion of occurence (vertebrates)

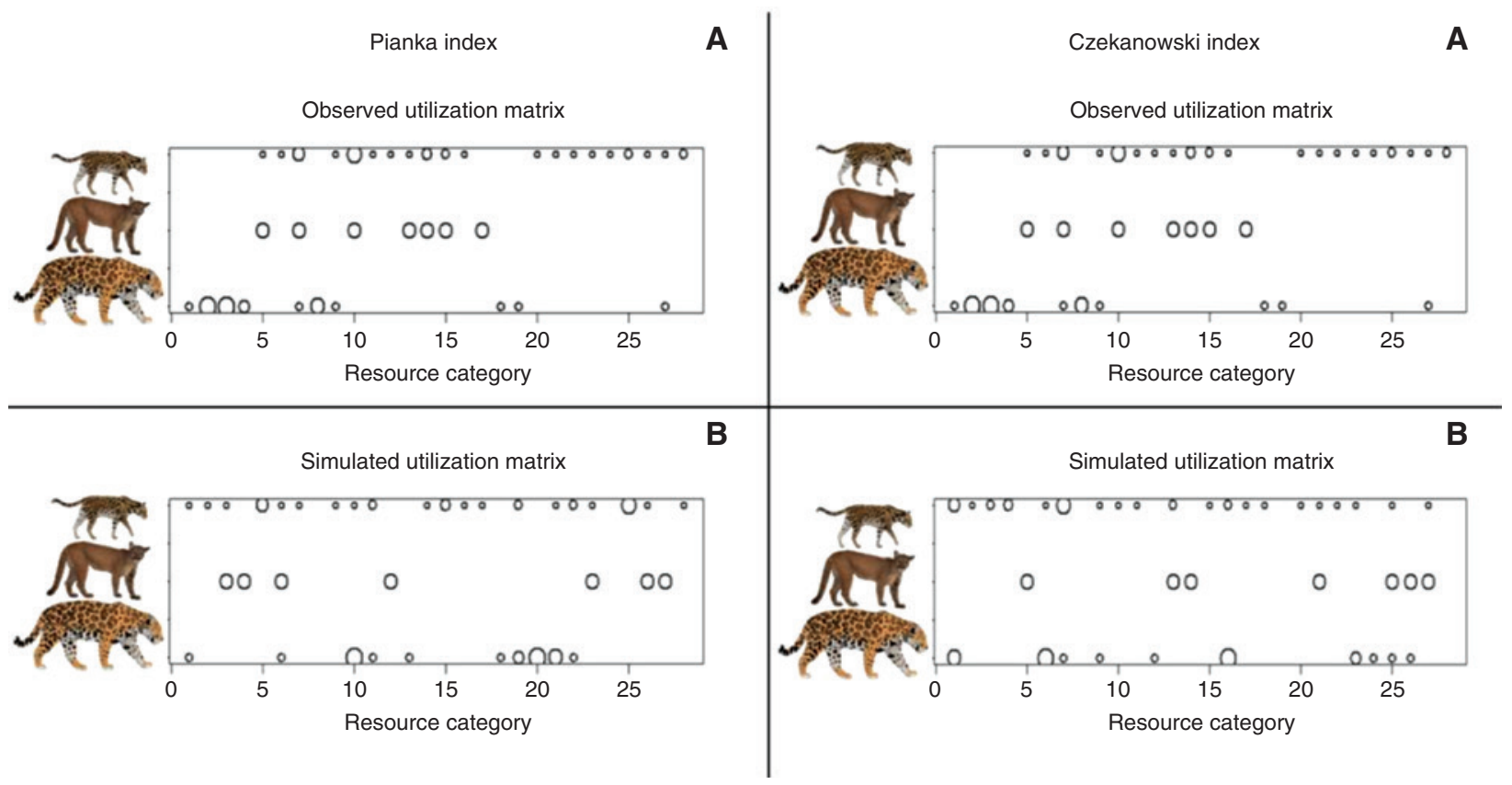

Figure 2: (A) Observed utilization matrix of ocelots (Leopardus pardalis), pumas (Puma concolor) and jaguars (Panthera onca) for the original proportion of occurrence $(P O)$ of vertebrate prey data from Alta Floresta, using Czekanowski's and Pianka's indices. (B) Simulated data matrix generated using 5000 repetitions.

The area of each circle is proportional to the utilization of a resource category by a species. If no circle is shown, the utilization was 0 . The result for Pianka's index was not significantly different from the expected by chance (observed index $=0.28$, mean of simulated index $=0.31$, $p=0.38$ ), as was also observed for the Czekanowski's index (observed index $=0.21$, mean of simulated index $=0.25, p=0.24$ ).

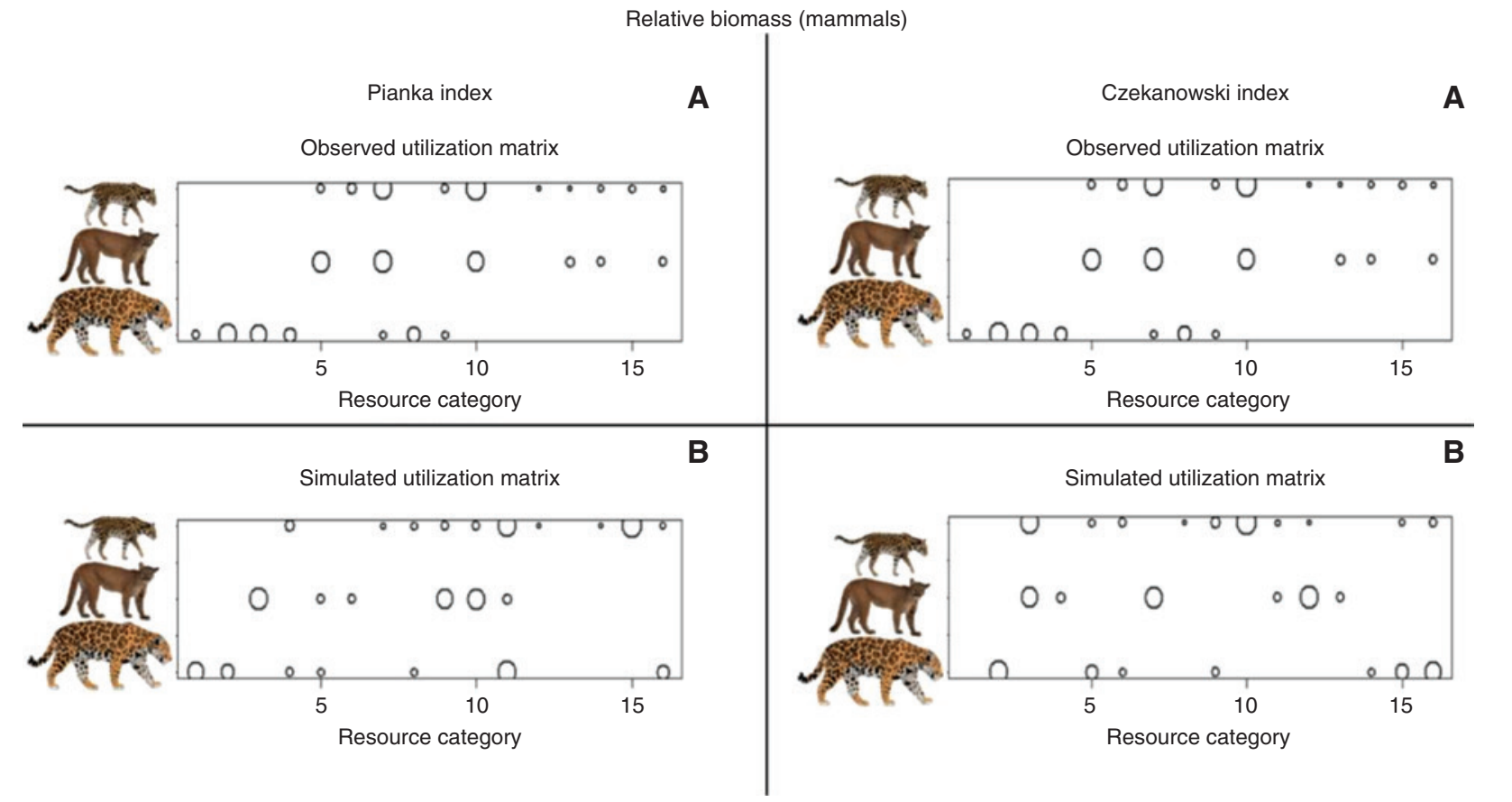

Figure 3: (A) Observed utilization matrix of ocelots (Leopardus pardalis), pumas (Puma concolor) and jaguars (Panthera onca) for the relative biomass $(R B)$ of mammal prey data matrix from Alta Floresta, Brazil, assessed with two different indices: Czekanowski and Pianka. (B) Simulated data matrix generated using 5000 repetitions.

The area of each circle depicted is proportional to the utilization of a resource category by a species; if no circle is shown, the utilization was 0 . The result for both indices was not significantly different from random expectations (Pianka: observed $=0.33$, mean of simulated index $=0.29, p=0.68$; Czekanowski: observed $=0.27$, mean of simulated index $=0.27, p=0.58$ ). 


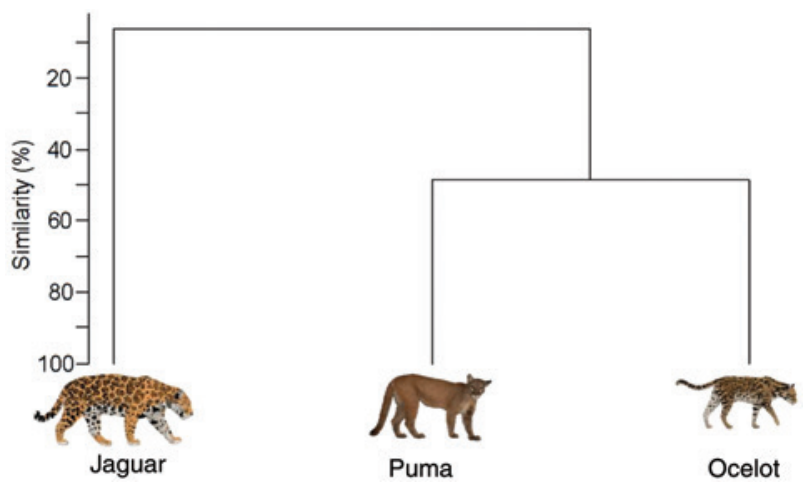

Figure 4: Cluster analysis of Bray-Curtis similarity indices of vertebrate prey species identified in faecal samples of jaguars (Panthera onca), pumas (Puma concolor) and ocelots (Leopardus pardalis) in Alta Floresta, Brazilian Amazon.

studies (Foran et al. 1997, Farrell et al. 2000, Prugh and Ritland 2005). Deformation in faecal samples, overlap in measurement among species and no significant difference between species, all argue against the use of this method.

\section{Carnivoran diet in a highly deforested region of the Brazilian Amazon}

An initial assessment including all the sampled predator species demonstrated that the majority of them consumed more mammals relative to other groups, except for the crab-eating fox and the semi-aquatic predators [neotropical otter (Lontra longicaudis) and giant otter (Pteronura brasiliensis) - the former had a more diverse diet and the latter had a diet based on fish]. Among the species with sufficient samples to perform quantitative analyses, the crab-eating fox was the one with the largest number of prey categories, indicating that its predation strategy seems generalist and opportunistic. Insects were the most consumed animals per scat, and Coleoptera was the most commonly observed order, as reported in a previous study (Rocha et al. 2008). Among the vertebrate prey, we found different results relative to previous studies, with Squamata being more frequent than mammals. The most frequent items based on their $P O$ were seeds/fruits, which agrees with other studies conducted in tropical areas (Jácomo et al.2004, Gatti et al. 2006). We also found plastic in the faeces of this species. Given the advance of urban and rural landscapes over the forest in this region, the contact of humans and wildlife has increased. Additionally, as the crab-eating fox seems to have considerable flexibility in its habitat use (Bianchi et al. 2016), including human-dominated landscapes (Pedó et al. 2006,
Rocha et al. 2008), this would also increase its exposure to anthropogenic waste, which may explain the presence of this material in its faeces.

The most important prey item for jaguars was the white-lipped peccary (Tayassu pecari), followed by the collared peccary (Pecari tajacu), both of which were reported among the three most important items in almost every dietary study of this species (Scognamillo et al. 2003, Azevedo and Murray 2007, Azevedo 2008). Both species of peccaries are a group-living species, and may pose a high injury risk for predators, as documented in some studies. For example, there is at least one record of a sub-adult female jaguar killed by collared peccaries (Scognamillo et al. 2003). Even with these risks, the results provided by this study suggest that jaguars may select for an effective energy gain by preying upon peccaries. The consumption of livestock by this predator was observed in the study, an occurrence that has been well documented by other studies in Brazil (Azevedo 2008, Silveira et al. 2008, Cavalcanti and Gese 2010, Marchini and Macdonald 2012) and in the study region in particular (Michalski et al. 2006). This is occurring due to the expansion of cattle ranching, which has severely increased deforestation in the Brazilian Amazon, replacing natural areas with extensive pastures; as a consequence, livestock has become an alternative prey for large felids.

The puma exhibited a broad range of prey size and feeding strategies in Alta Floresta. The results of the present study found puma to prey primarily on mediumsized mammals, as was observed by Emmons (1987) for the western Amazon. Ocelots preyed primarily on small- to medium-sized mammals, similarly to patterns reported in previous studies (Emmons 1987, Wang 2002, Bianchi et al. 2014). In this species' diet, three species of small mammals were different from those consumed by the puma. An interesting observation was that these prey species are typical of forest areas, while those shared with puma are typical of edge areas between forest and open landscapes. In one particular case, we observed that an ocelot had preyed upon a juvenile white-lipped peccary, probably as an opportunistic event, as there is no record of ocelots preying upon large-bodied peccaries (Villa-Meza et al. 2002, Moreno et al. 2006, Abreu et al. 2008, Bianchi et al. 2010, 2014, Santos et al. 2014). This observation was similar to VillaMeza et al.'s (2002) results in Mexico, which included evidence of subadult white-tailed deer (Odocoileus virginianus) in ocelot scats, suggesting that ocelots may capture non-adult individuals of larger prey.

Using different methods of estimation, our results indicated that the trophic niches of jaguars and pumas were the least overlapping of the three pairs tested, suggesting 
that they are not competing strongly for the same food resources in this region. We also observed a large overlap in diet between pumas and ocelots. Although the sample size for pumas was low, we can hypothesize that jaguars prioritize large-sized prey, driving pumas to seek smaller ones, consequently increasing the competition between pumas and ocelots. Other studies observed similar results in areas where jaguars and pumas are sympatric: large and medium-sized prey species comprised the bulk of the jaguar diet, while pumas concentrated on mediumsized items. Thus, jaguars may influence prey selection by pumas, inducing character displacement in the latter towards smaller body size (Iriarte et al. 1990, Scognamillo et al. 2003, Azevedo 2008). Smaller body size as well as smaller prey size could increase the competition for food resources between pumas and ocelots. Accordingly, previous studies of pumas and ocelots observed that, when jaguars do not coexist with them, both species present lower dietary overlap (Iriarte et al. 1990, Moreno et al. 2006, Azevedo 2008, Martins et al. 2008). It is important to emphasise that with our number of samples we may not have results entirely consistent, especially concerning the perimeter of the scats and in niche overlap values, and we recognize that future studies with additional samples could achieve different results.

\section{Conclusion}

Despite the low number of samples evaluated in our study, it could be used as a guide for dietary and methodological comparative studies due to its innovative analytical methods. The use of a reliable method of species identification is crucial for studies based on faecal samples. In this study, we demonstrate that the two currently used methods are largely congruent, and can complement each other to maximize sample size in areas where obtaining a large number of samples is challenging. Regarding the dietary comparisons, we concluded that the three largest Neotropical felids can interfere with each other's diet in an asymmetric pattern, with jaguars driving the process and leading to shifts in the competitive dynamics of the other two. Additionally, our results also indicated that anthropogenic activities (wood harvesting and cattle ranching, favouring the expansion of rural and urban areas) are already affecting the feeding behaviour of carnivores in the area. As human activities are taking place over much of the Amazon, pristine habitats for prey and predators are decreasing, while conflicts between carnivores and humans tend to increase. The data generated in this study can contribute, as an initial assessment, to improve the understanding of carnivoran ecology in the southern Amazon, which should be useful in the context of conservation planning on behalf of this highly impacted region.

Acknowledgements: We gratefully acknowledge all museum curators who provided help: M. Jardim (Fundação Zoobotânica), J.A. de Oliveira (Museu Nacional, Universidade Federal do Rio de Janeiro), Z.M. de Lucena, and C. Fontana (Museu de Ciências e Tecnologia, Pontifícia Universidade Católica do Rio Grande do Sul). We especially thank professors M.B. Martins, L.R. Malabarba, and P. Barata for comments and suggestions. We also thank R. Moraes and P. Bugs for their help during the study. This study was financed in part by the Coordenação de Aperfeiçoamento de Pessoal de Nível Superior - Brasil (CAPES) - Finance Code 001. F.M. was funded by Fundação de Amparo à Pesquisa do Estado de São Paulo (FAPESP) post-doctoral scholarship during the study period [2007/01252-2] and currently receives a productivity scholarship from Conselho Nacional de Desenvolvimento Cientifico e Tecnológico (CNPq, Process 301562/2015-6) and is funded by CNPq (Process 403679/2016-8). A.R.P. would like to acknowledge logistic and financial support from Universidade de São Paulo, FAPESP and CNPq. E.E. is funded by CNPq and Fundação de Amparo à Pesquisa do Estado do Rio Grande do Sul (FAPERGS). This study was also funded by the Wildlife Conservation Society, Conservation, Food and Health Foundation, Cleveland Metroparks Zoo and the Cleveland Zoological Society and The Rufford Small Grants Foundation. The funders had no role in study design, data collection and analysis, decision to publish or preparation of the manuscript.

\section{References}

Abreu, K.C., R. Mororios, J. Silva-Pereira Miranda, E. Jablonski, and F. Passos. 2008. Feeding habits of ocelot (Leopardus pardalis) in Southern Brazil. Mamm. Biol. 73: 407-411.

Ackerman, B.B., F. Lindzey, and T. Hemker. 1984. Cougar food habits in southern Utah. J. Wildl. Manag. 48: 147-155.

Andheria, A.P., K. Karanth, and N. Kumar, 2007. Diet and prey profiles of three sympatric large carnivores in Bandipur Tiger Reserve, India. J. Zool. 273: 169-175.

Azevedo, F.C.C. 2008. Food habits and livestock depredation of sympatric jaguars and pumas in the Iguaçu National Park Area, South Brazil. Biotropica 40: 494-500.

Azevedo, F.C.C. and D. Murray. 2007. Spacial organization and food habits of jaguars (Panthera onca) in a floodplain forest. Biol. Conserv. 137: 39-402.

Baker, L.A., R. Warren, and W. James. 1993. Bobcat prey digestibility and representation in scats. 47th Annu. Conf. Southeast. Fish and Wildl. Agencies 47: 71-79. 
Baker, L.A., R. Warren, D. Diefenbach, W. James, and M. Conroy. 2001. Prey selection by reintroduced bobcats (Lynx rufus) on Cumberland Island, Georgia. The Amer. Midl. Nat. J. 145: 80-93.

Barlow, J., G.D. Lennox, J. Ferreira, E. Berenguer, A.C. Lees, R. Mac Nally, J.R. Thomson, S.F. Ferraz, J. Louzada, V.H. Oliveira, L. Parry, R.R. Solar, I.C. Vieira, L.E. Aragão, R.A. Begotti, R.F. Braga, T.M. Cardoso, R.C. de Oliveira Jr., C.M. Souza Jr., N.G. Moura, S.S. Nunes, J.V. Siqueira, R. Pardini, J.M. Silveira, F.Z. Vaz-de-Mello, R.C. Veiga, A. Venturieri, and T.A. Gardner. 2016. Anthropogenic disturbance in tropical forests can double biodiversity loss from deforestation. Nature 535: 144-147.

Bianchi, R.C., S.L. Mendes, and P.D.M Junior. 2010. Food habits of the ocelot, Leopardus pardalis, in two areas in southeast Brazil. Stud. Neotrop. Fauna. Environ. 45: 111-119.

Bianchi, R.C., R.C. Campos, N.L. Xavier-Filho, N. Olifiers, M.E. Gompper, and G. Mourão. 2014. Intraspecific, interspecific, and seasonal differences in the diet of three mid-sized carnivores in a large neotropical wetland. Acta Theriol. 59: 13-23.

Bianchi, R.C., N. Olifiers, M.E. Gompper, and G. Mourão. 2016. Niche partitioning among mesocarnivores in a Brazilian Wetland. PLoS One 11: e0162893.

Bonvicino, C.R., J. Oliveira, and P. D’Andrea. 2008. Guia dos roedores do Brasil, com chaves para gêneros baseadas em caracteres externos. OPAS/OMS, Rio de Janeiro.

Bray, R.J. and J.T. Curtis. 1957. An ordination of the upland forest communities of southern Wisconsin. Ecol. Monogr. 27: 325-349.

Brom, T.G. 1986. Microscopic identification of feathers and feather fragments of palearctic birds. Bijdragen tot de dierkunde 56 : 181-204.

Cabral, M.M., J. Zuanon, G.E. de Mattos, and F.C. Rosas. 2010. Feeding habits of giant otters Pteronura brasiliensis (Carnivora: Mustelidae) in the Balbina hydroelectric reservoir, Central Brazilian Amazon. Zoologia (Curitiba) 27: 47-53.

Campos, B. 2009. Dieta de carnívoros e uso de espaço por mamíferos de médio e grande porte em áreas de silvicultura do estado de São Paulo, Brasil. PhD dissertation, Escola Superior de Agricultura Luiz de Queiroz, Piracicaba, S.P.

Carss, D.N. and S.G. Parkinson. 1996. Errors associated with otter Lutra Lutra fecal analysis. Assessing general diet from spraints. J. Zool. 238: 301-317.

Cavalcanti, S.M.C. and E. Gese. 2010. Kill rates and predation patterns of jaguars (Panthera onca) in the southern Pantanal, Brazil. J. Mammal. 91: 722-736.

Chaves, P.B., V.G. Graeff, M.B. Lion, L.R. Oliveira, and E. Eizirik. 2012. DNA barcoding meets molecular scatology: short mtDNA sequences for standardized species assignment of carnivore noninvasive samples. Mol. Ecol. 12: 18-35.

De la Torre, J.A. and G. De la Riva. 2009. Food habits of pumas (Puma concolor) in a semiarid region of central Mexico. Mastozool. Neotrop. 16: 211-216.

Emmons, L.H. 1987. Comparative feeding ecology of felids in a Neotropical rainforest. Behav. Ecol. Sociobiol. 20: 271-283.

Farrell, L.E., J. Roman, and M. Sunquist. 2000. Dietary separation of sympatric carnivores identified by 18 molecular analysis of scats. Mol. Ecol. 9: 1583-1590.

Foran, D.R., K. Crooks, and S. Minta. 1997. Species identification from scat: an unambiguous genetic method. Wildl. Soc. Bull. 25: 835-839.
Gatti, A., R. Bianchi, C. Rosa, and S. Mendes. 2006. Diet of two sympatric carnivores, Cerdocyon thous and Procyon cancrivorus, in a restinga area of Espirito Santo State, Brazil. J. Trop. Ecol. 22: 227-230.

Gotelli, N.J., E.M. Hart, and A.M. Ellison. 2015. EcoSimR: Null model analysis for ecological data. $\mathrm{R}$ package version 0.1.0. http://github.com/gotellilab/EcoSimR. doi:10.5281/ zenodo.16522.

Iriarte, J.A., W. Franklin, W. Johnson, and K. Redford. 1990. Biogeographic variation of food habits and body size of the American puma. Oecologia 85: 185-190.

Jácomo, A.T.A., L. Silveira, and J. Diniz-filho. 2004. Niche separation between the maned wolf (Crysocyon branchyurus), the crab-eating fox (Dusicyon thous) and the hoary fox (Dusicyon vetulus) in central Brazil. J. Zool. 262: 99-106.

Köppen, W. 1948. Climatologia: con un estudio de los climas de la tierra. Fondo de Cultura Econômica, México.

Krebs, C.J. 1999. Ecological methodology. Addison-Welsey Educational Published, New York.

Macdonald, D.W. and A.J. Loveridge. 2010. Biology and conservation of wild felids. Oxford University Press, Oxford.

Malhi, Y., J.T. Roberts, R.A. Betts, T.J. Killeen, W. Li, and C.A. Nobre. 2008. Climate change, deforestation, and the fate of the Amazon. Science 319: 169-172.

Marchini, S. and D.W. Macdonald. 2012. Predicting ranchers' intention to kill jaguars: case studies in Amazonia and Pantanal. Biol. Cons. 147: 213-221.

Martínez-Gutiérrez, P.G., F. Palomares, and N. Fernández. 2015. Predator identification methods in diet studies: uncertain assignment produces biased results? Ecography 38: 922-929.

Martins, R., J. Quadros, and M. Mazzolli. 2008. Hábito alimentar e inferência antrópica na atividade de marcação territorial do Puma concolor e Leopardus pardalis (Carnívora, Felidae) e outros carnívoros na Estação Ecológica de Juréia-Itatins, São Paulo, Brasil. Rev. Bras. Zool. 25: 427-435.

Michalski, F. and C.A. Peres. 2007. Disturbance-mediated mammal persistence and abundance-area relationships in Amazonian forest fragments. Conser. Biol. 21: 1626-1640.

Michalski, F. and C.A. Peres. 2017. Gamebird responses to anthropogenic forest fragmentation and degradation in a southern Amazonian landscape. PeerJ. 5: e3442.

Michalski, F., R. Boulhosa, A. Faria, and C.A. Peres. 2006. Humanwildlife conflicts in a fragmented Amazonian forest landscape: determinant of large felid depredation on livestock. Anim. Conserv. 9: 178-188.

Michalski, F., C.A. Peres, and I.R. Lake, 2008. Deforestation dynamics in a fragmented region of southern Amazonia: evaluation and future scenarios. Environ. Conserv. 35: 93-103.

Michalski, F., F.P. Valdez, D. Norris, C. Zieminski, C.K. Kashivakura, C.S. Trinca, H.B. Smith, C. Vynne, S.K. Wasser, J.P. Metzger, and E. Eizirik. 2011. Successful carnivore identification with fecal DNA across a fragmented Amazonian landscape. Mol. Ecol. 11: 862-871.

Miller, B. and A. Rabinowitz. 2002. ¿Por qué conservar el jaguar? In: (R.A. Medellin, C. Chetkiewicz, A. Rabinowitz, K.H. Redford, J.G. Robinson, E. Sanderson and A. Taber, eds.) El jaguar en nuevo milenio. Universiudad Nacional Autónoma de México and Wildlife Consevation Society, New York, NY. pp. 303-315.

Moreno, R.S., R. Kays, and R. Samudio. 2006. Comparative release in diet of ocelot (Leopardus pardalis) and puma (Puma 
concolor) after jaguar (Panthera onca) decline. J. Mammal. 87: 808-816.

Morin, D.J, S.D. Higdon, J.L. Holub, D.M. Montague, M.L. Fies, L.P. Waits, and M.J. Kelly. 2016. Bias in carnivore diet analysis resulting from misclassification of predator scats based on field identification. Wildl. Soc. Bull. 40: 669-677.

Napolitano, C., M. Bennet, W. Johnson, S. O’Brien, P. Marquet, I. Barría, E. Poulin, and A. Iriarte. 2008. Ecological and biogeographical inferences on two enigmatic Andean cat species using genetic identification of fecal samples. Mol. Ecol. 17: 678-690.

Norris, D. and F. Michalski. 2010. Implications of faecal removal by dung beetles for scat surveys in a fragmented landscape of the Brazilian Amazon. Oryx 44: 455-458.

Oksanen, J., F.G. Blanchet, M. Friendly, R. Kindt, P. Legendre, D. McGlinn, P.R. Minchin, R.B. O'Hara, G.L. Simpson, P. Solymos, M.H.H. Stevens, E. Szoecs, and H. Wagner. 2017. Vegan: community ecology package. $R$ package version 2.4-4.

Pedó, E., A. Tomazzoni, S. Hartz, and A. Cristoff. 2006. Diet of crabeating fox, Cerdocyon thous (Linnaeus) (Carnivora, Canidae), in a suburban area of southern Brazil. Rev. Bras. Zool. 23: 637-641.

Pianka, E.R. 1973. The structure of lizard communities. Annu. Rev. Ecol. Evol. Syst. 4: 53-74.

Pinkas, L., M.S. Oliphante, and I.L.K. Iverson. 1971. Food habits of albacore, bluefin tuna and bonito in California waters. Calif. Fish Game 152: 1-105.

Prugh, L.R. and C. Ritland. 2005. Molecular testing of observer identification of carnivore feces in the field. Wildl. Soc. Bull. 33: 189-194.

Quadros, J. and E. Monteiro-Filho. 2006a. Coleta e preparação de pêlos de mamíferos para a identificação em microscopia óptica. Rev. Bras. Zool. 23: 274-278.

Quadros, J. and E. Monteiro-Filho. 2006b. Revisão conceitual, padrões microestruturais e proposta nomenclatória para pêlosguarda de mamíferos brasileiros. Rev. Bras. Zool. 23: 279-292.

R Core Team. 2015. R: a language and environment for statistical computing. R Foundation for Statistical Computing, Vienna, Austria. ISBN 3-900051-07-0.

Radam-Brasil. 1983. Projeto Radam-Brasil: levantamento de recursos naturais. IBGE, Rio de Janeiro, R.J.

Ramalho, E.E. 2006. Uso do habitat e dieta da onça-pintada (Panthera onca) em uma área de várzea, Reserva de Desenvolvimento Sustentável Mamirauá, Amazônia Central, Brasil. Manaus. MSc. disseration Programa de Pós-Graduação em Biologia Tropical e Recursos Naturais INPA/UFAM, Brazil.

Rocha, V.J., L. Aguiar, J. Silva-Pereira, R. Moro-Rios, and F. Passos. 2008. Feeding habits of the crab-eating Fox, Cerdocyon thous (Carnivora: Canidae), in a mosaic area with native and exotic vegetation in Southern Brazil. Rev. Bras. Zool. 25: 594-600.
Rocha-Mendes, F., S.B. Mikich, J. Quadros, and W.A. Pedro. 2010. Feeding ecology of carnivores (Mammalia, Carnivora) in Atlantic forest remnants, southern Brazil. Biota Neotrop. 10: 21-30.

Rosas, F.C., J.A. Zuanon, and S.K. Carter. 1999. Feeding ecology of the giant otter, Pteronura brasiliensis. Biotropica 31: 502-506.

Santos, J.L., A.M.O. Paschoal, R.L. Massara, and A.G. Chiarello. 2014. High consumption of primates by pumas and ocelots in a remnant of the Brazilian Atlantic Forest. Braz. J. Biol. 74: 632-641.

Scognamillo, D., E. Maxit, M. Sunquist, and J. Polisar. 2003. Coexistence of jaguar (Panthera onca) and puma (Puma concolor) in a mosaic landscape in the Venezuelan Ilanos. J. Zool. 259: 269-279.

Silva-Pereira, J.E. 2009. Dieta de três espécies simpátricas de felídeos - Leopardus pardalis, Leopardus tigrinus e Puma yagouaroundi (Carnivora, Felidae) - em Floresta Ombrófila Mista e Campos Gerais, Paraná, sul do Brasil. M.Sc. dissertation, Department of Zoology, Universidade do Paraná, Curitiba, Brazil.

Silveira, L., R. Boulhosa, S. Astete, and A. Jácomo. 2008. Management of domestic livestock predation by jaguars in Brazil. Cat News 4: 26-30.

Sørensen, T. 1948. A method of establishing groups of equal amplitude in plant sociology based on similarity of species and its application to analyses of the vegetation on Danish commons. Biologiske Skrifter/Kongelige Danske Videnskabernes Selskab. 5: 1-34.

Sunquist, M.E. and F. Sunquist. 1989. Ecological constraints on predation by large felids. In: (J.L. Gittleman, ed.) Carnivore behaviour ecology and evolution. Cornell University, New York, NY. pp. 283-301.

Terborgh, J., L. Lopez, P. Nuñez, M. Rao, G. Shahabuddin, G. Orihuela, M. Riveros, R. Ascanio, G.H. Adler, T.D. Lambert, and L. Balbas. 2001. Ecological meltdown in predator-free forest fragments. Science 294: 923.

Villa-Meza, A., E. Meyer, and C. González. 2002. Ocelot (Leopardus pardalis) food habits in a tropical deciduous forest of Jalisco, Mexico. Amer. Midl. Nat. J. 148: 146-154.

Wang, E. 2002. Diets of ocelots (Leopardus pardalis), margays (L. wiedii) and oncillas (L. tigrinus) in the Atlantic rainforest in Southeast Brazil. Stud. Neotrop. Fauna Environ. 37: 207-212.

Weaver, J.L. 1993. Refining the equation for interpreting prey occurrence in wolf scats. J. Wild. Mang. 57: 534-538.

Zhang, J. 2016. Package 'spaa' R package version 0.2.2.

Supplementary Material: The online version of this article offers supplementary material (https://doi.org/10.1515/mammalia-20180106). 